\title{
MENUMBUHKAN KARAKTER KEWIRAUSAHAAN PESERTA BELAJAR DI PUSAT KEGIATAN BELAJAR MENGAJAR (PKBM) AL KAHFI BATURAJA
}

\author{
Angga Wibowo Gultom ${ }^{1 *}$, Yudi Tusri ${ }^{2}$, Anton Kurniawan ${ }^{3}$, Muznah $^{4}$ \\ ${ }^{1}$ Universitas Baturaja \\ ${ }^{2}$ STIE Prabumulih \\ ${ }^{3}$ Universitas Sumatera Selatan \\ ${ }^{4}$ Universitas Baturaja \\ *mr.angga.gultom@gmail.com
}

\begin{abstract}
ABSTRAK
Wirausaha memiliki kontribusi yang sangat baik dalam penciptaan lapangan kerja, pengurangan pengangguran, penambahan pendapatan masyarakat serta berkontribusi besar terhadap perputaran perekonomian negara. Untuk itu pemerintah melalui program kementrian pendidikan mengeluarkan program kecakapan wirausaha untuk mendorong lahirnya wirausaha baru bagi masyarakat diusia produktif yang belum memiliki pekerjaan dan tidak sedang berkuliah. Kegiatan Pengabdian pada masyarakat ini bertujuan untuk mempersiapkan pola pikir, menumbuhkan motivasi dan menanamkan alasan kuat bagi 20 orang peserta program kecakapan wirausaha di PKMB alkahfi agar siap menjadi wirausaha baru. Metode yang digunakan adalah presentasi, focus group discussion, tanya jawab, diskusi, game dan roleplay. Hasil pengabdian kepada masyarakat ini menunjukan bahwa keseluruh peserta memiliki pola pikir baru, memahami karakter wirausaha, berhasil menghancurkan mental blok dan memiliki motivasi tinggi untuk menjadi wirausaha baru.
\end{abstract}

Kata kunci: Karakter, Kewirausahaan, Pusat Kegiatan Belajar Masyarakat

\begin{abstract}
Entrepreneurs having significant contribution in creating job opportunities, reducing unemployment, increasing people's income and contributing greatly to the country's economic cycle. For this reason, the government through the Ministry of Education program issued an entrepreneurial skills program to encourage of new entrepreneurs for productive age who do not have a job and are not currently studying. This community service activity aims to prepare mindsets, motivation and strong reasons for 20 participants in the entrepreneurial skills program at PKMB Alkahfi in order to be ready to become new entrepreneurs. The methods used are presentation, focus group discussion, questions and answer, discussion, game and roleplay. The results of this community service show that all participants have a new mindset, understand the character of entrepreneurship, succeed in destroying mental blocks and have high motivation to become new entrepreneurs.
\end{abstract}

Keywords: Character, Entrepreneurship, Community Learning Activity Center

\section{PENDAHULUAN}

Wirausaha merupakan sesorang yang mampu menciptakan lapangan kerja bagi orang lain, hal ini sangat penting karena penciptaan banyak lapangan kerja akan memiliki kontribusi 
Prosiding The 1st National Conference on Applied Business, Education, \& Technology (NCABET)"

Unversitas Bina Bangsa 2021

DOI Article : 10.46306/ncabet.v1i1.13

besar terhadap produktifitas banga, terutaa dalam mengentaskan kemiskinan, termasuk menjadi solusi permasalahan sosial (Sulastri, 2016). Istilah wirausaha atau kewirausahaan sendiri berasal dari padanan kata entrepreneurship dalam bahasa inggris. kata entrepreneurship sendiri sebenarnya berasal dari Bahasa Perancis yaitu entreprende yang artinya ialah petualang, pencipta dan pengelola usaha. Istilah kewirausahaan sendiri dipopulerkan oleh eono J.B. Say untuk mendeskripsikan pra pengusaha yang mampu memindahkan sumber daya ekonomis dari tingkat produktivitas rendah menjadi bernilai tinggi (Suryana \& Bayu, 2012).

Saat ini kontribusi wirausaha bagi negara sangat tinggi, hal ini terlihat dari kontribusi wirausaha dikategori usaha mikro kecil dan menengah yang mampu menopang ekonomi nasional dengan jumlah 64 juta usaha yang juga berarti 99,99\% usaha yang ada di indonesia adalah wirausaha UMKM (Apip Alansori \& Erna Listyaningsih, 2020). Tingginya kontribusi wirausaha UMKM ini sudah selayaknya didukung dengan berbagai program pemerintah, diantaranya ialah dengan mulai menyiapkan generasi muda untuk menjadi wirausaha milineal baru.

Generasi muda dari kalangan milineal sangat penting untuk mulai masuk dalam dunia usaha karena dapat memberikan kontribusi inovasi dalam memajukan perekonomian di Indonesia yang lebih baik lagi dimasa yang akan datang (Fernando \& Jamaaluddin, 2020). Kemajuan ini dapat dilihat dari tumbuhnya ekonomi kreatif yang hadir karena berkembangnya kewirausahaan yang kreatif dan mendukung ekonomi daerah (Barlian et al., 2014). Ekonomi daerah yang didukung oleh pemuda ini berarti pertumbuhan ekonomi yang terjadi bukan hanya dikota, namun juga hingga ke desa. para wirausaha muda yang ada didesa dapat menjadi solusi terhadap permasalahan sosial seperti kemiskinan, minimnya tenaga kerja pertanian maupun rendahnya kualitas pelayanan sosial di desa (Puspitasari, 2015).

Peran serta generasi muda yang baru mau memulai menjadi wirausaha tidak bisa serta merta terwujud dengan mudah, beberapa faktor penghalang seperti bagaimana memulai usaha, apa yang harus dilakukan, serta bagaimana membuat rencana yang baik dalam usaha adalah sebagian kecil permasalahan yang mereka hadapi, untuk itu diperlukan solusi pendampingan agar wirausaha pemula ini dapat berhasil (Sarah et al., 2020). Untuk itu sangat penting bagi pemerintah dan berbagai elemen masyarakat untuk melakukan program pembinaan dan pendampingan bagi wirausaha baru. Selain program pendampingan, faktor yang juga penting dan berpengaruh terhadap keberhasilan wirausaha adalah keberhasilan diri dalam berwirauaha (Mahesa \& Rahardja, 2012). 
Memahami bahwa program pendampingan bagi pemuda untuk menjadi wirausaha baru sangatlah penting, maka pemerintah melalui kementrian pendidikan meluncurkan program kecakapan wirausaha. Program ini adalah program inkubator bisnis yang dilaksanakan oleh lembaga pendidikan kursus maupun pusat kegiatan belajar masyarakat (PKBM). Program ini menyaring pemuda usia produktif yang masih menganggur dan tidak sedang berkuliah untuk dididik menjadi wirausaha baru dengan berbagai jenis kecakapan seperti kuliner, otomotif, menjahit, las dan berbagai jenis keterampilan lainnya.

Kegiatan program kecakapan kerja (PKW) dari kementrian pendidikan ini dilaksanakan diseluruh Indonesia, termasuk di kota Baturaja, Kabupaten Ogan Komering Ulu Provinsi Sumatera-Selatan. Salah satu lembaga pendidikan yang melaksanakan kegiatan ini adalah pusat kegiatan belajar mengajar (PKBM) Alkahfi yang beralamat di daerah Kemelak Kecamatan Baturaja Timur. Pusat kegiatan belajar mengajar (PKBM) Alkahfi mendapatkan program kecakapan wirausaha rumpun pariwisata dengan jenis keterampilan jasa usaha makanan dengan jumlah peserta sebanyak 20 orang pemuda usia produktif yang belum bekerja dan tidak sedang kuliah.

Untuk bisa membuat para peserta kegiatan menjadi wirausaha, tentu tidak serta merta langsung membuat produk dan memasarkan produk yang dibuat tersebut. Dibutuhkan perubahan atau shifting mainset terlebih dahulu dari yang awalnya belum sama sekali mengenal kegiatan wirausaha menjadi orang yang termotivasi dan memiliki keinginan kuat untuk menjadi wirausaha. Inilah tujuan kegiatan pengabdian kepada masyarakat ini, yaitu memberikan materi tentang karakter kewirausahaan kepada para peserta kegiatan program kecakapan wirausaha agar para peserta memiliki pola pikir dan paradigma positif tentang wirausaha dan termotivasi untuk menjadi wirausaha baru, sesuai dengan harapan dari pelaksanaan program kecakapan wirausaha ini.

Penanaman pola pikir wirausaha sangat penting bagi para peserta kegiatan yang memang belum pernah sama sekali menjadi wirausaha, hal ini disebabkan dikarena mereka pasti akan menghadapi lingkungan wirausaha yang memiliki tingkat ketidakpastian yang tinggi dan memiliki resiko. Untuk itulah pola pikir wirausaha harus diberikan sejak dini, agar para peserta dapat selalu termotivasi dan produktif untuk melahirkan inovasi-inovasi baru dalam membaca dan menciptakan peluang dilingkungan masyarakat (Dede Andi, 2021).

Kegiatan pengabdian pada masyarakat ini diharapkan dapat menanamkan serta menumbuhkan karakter kewirausahaan yang utuh dan komprehensif bagi para peserta program kegiatan kecakapan wirausaha rumpun pariwisata dengan jenis keterampilan jasa usaha makanan di pusat kegiatan belajar mengajar (PKBM) Alkahfi, sehingga output dari program 
Prosiding The 1st National Conference on Applied Business, Education, \& Technology (NCABET)"

Unversitas Bina Bangsa 2021

DOI Article : 10.46306/ncabet.v1i1.13

kementerian pendidikan untuk menghasilkan wirausaha baru yang berasal dari usia muda produktif dapat terwujud dengan baik sesuai harapan yang dicita-citakan.

\section{METODE PELAKSANAAN}

Kegiatan pengabdian pada masyarakat ini dilaksanakan di pusat kegiatan belajar masyarakat (PKBM) Alkahfi Baturaja yang terletak di Kabupaten Ogan Komering Ulu dengan sistem tatap muka yang menerapkan protokol kesehatan. Kegiatan tatap muka dilakukan selama tiga hari pada tanggal 29, 30 Juni dan 1 Juli 2021 dengan total 10 jam pengajaran. Kegiatan pelaksanaan ini mencakup tiga hal yaitu:

1. Kegiatan Presentasi oleh Pemateri

Merupakan pemaparan materi oleh narasumber yang berisi tentang karakteristik wirausaha baik pembahasan secara teori maupun pembahasan studi kasus yang terjadi. Pemaparan presentasi ini menggunakan slide power point dan infokus dengan sistem tatap muka.

2. Focus Group Discussion

Memberikan studi kasus tentang karakteristik kewirausahaan kepada para peserta kegiatan oleh narasumber untuk dipecahkan bersama secara berkelompok, focus group discussion ini bertujuan untuk meningkatkan rasa percaya diri serta kemampuan peserta untuk berani menyampaikan ide dan pendapatnya.

3. Tanya Jawab dan diskusi

Memberikan kesempatan bagi para peserta untuk memberikan pertanyaan dan mendiskusikannya bersama narasumber, hal ini sangat penting agar para peserta dapat memiliki pemahaman yang utuh tentang materi yang diberikan oleh narasumber.

4. Game and roleplay

Dilakukan disela-sela materi untuk membuat peserta tetap bersemangat dan fokus untuk mengikuti materi yang dipresentasikan. Game dan roleplay tentang karakter kewirausahaan juga dilakukan untuk membuka mindset para peserta tentang paradigma baru yang harus ditumbuhkan dan mengeluarkan mereka dari zona nyaman yang saat ini mereka rasakan.

5. Presentasi Individu oleh Peserta Kegiatan

Merupakan kegiatan akhir yang dilakukan untuk dijadikan bahan evaluasi apakah kegiatan pengabdian pada masyarakat ini berhasil untuk menanamkan dan menumbuhkan karakter wirausaha bagi para peserta. Kegiatan ini dilakukan dengan 
cara peserta maju satu persatu kedepan dan melakukan presentasi tentang motivasi dan pemahaman mereka tentang karakter wirausaha dan kesiapan mereka untuk menjadi wirausaha baru.

\section{HASIL DAN PEMBAHASAN}

Hasil dari kegiatan pengabdian pada masyarakat pada program kegiatan kecakapan wirausaha rumpun pariwisata dengan jenis keterampilan jasa usaha makanan di pusat kegiatan belajar mengajar (PKBM) Alkahfi akan dijelaskan berdasarkan materi yang diberikan per hari, sehingga pembahasan akan dibagi menjadi tiga bagian dikarenakan kegiatan ini dilaksanakan selama 3 hari dengan nilai 10 jam pelajaran. Pembagian ini dibuat agar hasil dan pembahasan lebih terstruktur dan rapi. Berikut merupakan hasil dan pembahasan kegiatan pengabdian pada masyarakat.

\section{Pengenalan Tentang Wirausaha (Hari Pertama)}

Sebelum masuk memberikan materi tentang kewirausahaan, sangat penting untuk mengetahui pemahaman peserta kegiatan program kegiatan kecakapan wirausaha rumpun pariwisata dengan jenis keterampilan jasa usaha makanan di pusat kegiatan belajar mengajar (PKBM) Alkahfi, Hal ini untuk mengetahui sejauh apa pemahaman yang saat ini dimiliki para peserta, sehingga narasumber dapat memberikan materi sesuai dengan kapasitas yang dimiliki oleh para peserta. Output awal kegiatan ini adalah mengetahui pola pikir peserta kegiatan tentang wirausaha.

Kegiatan pertama yang dilakukan adalah focus group discussion bersama para peserta dengan hasil bahwa seluruh peserta pada dasarnya sudah memahami arti wirausaha, bahkan 30\% peserta kegiatan atau sebanyak 6 orang, pernah mencoba untuk melakukan kegiatan wirausaha, namun demikian dikarenakan tidak adanya program pendampingan, maka mereka merasa kegiatan wirausaha mereka tidak berkembang. Sedangkan $70 \%$ peserta kegiatan lain sudah memahami tentang kegiatan wirausaha, namun memiliki rasa takut untuk mencoba melakukan kegiatan wirausaha, hal ini dikarenakan mereka belum memiliki pengetahuan bagaimana cara untuk memulai menjadi wirausaha.

Setelah mendapatkan hasil dari focus group discussion, maka selanjutnya narasumber memberikan materi tentang pengenalan wirausaha yang meliputi, arti dari wirausaha, bagaimana memulai menjadi wirausaha, serta contoh wirausaha yang sukses. Materi ini diberikan secara pemaparan langsung didepan para peserta dilanjutkan dengan tanya jawab dan diskusi sebagai bagaian dari pendalaman materi bagi para peserta. 
Prosiding The 1st National Conference on Applied Business, Education, \& Technology (NCABET)"

Unversitas Bina Bangsa 2021

DOI Article : 10.46306/ncabet.v1i1.13

Hasil pemaparan materi dan tanya jawab menunjukan bahwa para peserta kegiatan kecakapan wirausaha rumpun pariwisata dengan jenis keterampilan jasa usaha makanan di pusat kegiatan belajar mengajar (PKBM) Alkahfi memiliki tingkat antusias dan semangat yang tinggi untuk mengetahui tentang dunia wirausaha termasuk karakter untuk menjadi wirausaha yang sukses. Materi pengenalan wirausaha termasuk contoh kasus kesuksesan wirausaha muda memberikan mereka motivasi untuk memiliki rasa ingintahu yang tinggi. Hal ini sangat bagus, karena ini berarti para peserta sudah berani terbuka untuk menyampaikan pendapatnya dan memiliki rasa percaya diri yang baik dalam menyampaikan ide dan pimikiran mereka.

2. Pola Pikir dan Karakter Wirausaha (Hari Kedua)

Berdasarkan hasil kegiatan pengabdian dihari pertama tentang kesiapan dan minat peserta kegiatan kecakapan wirausaha rumpun pariwisata dengan jenis keterampilan jasa usaha makanan di pusat kegiatan belajar mengajar (PKBM) Alkahfi dapat diketahui bahwa para peserta kegiatan memiliki antusiasme dan keinginan yang tinggi untuk menjadi wirausaha dan mengenal lebih jauh tentang pola pikir dan karakter wirausaha, untuk itulah narasumber memberikan materi ini dihari kedua sesuai dengan tingkat kesiapan peserta dalam menerima materi yang diberikan.

Pola pikir dan karakter wirausaha disampaikan dengan cara presentasi oleh narasumber dan diselingi tanya jawab dengan para peserta. Kegiatan pola pikir yang pertama menekankan kepada materi strong reason atau alasan kuat yang harus dimiliki para peserta untuk menjadi wirausaha, karena tanpa memiliki alasan yang kuat atau sekedar ikut-ikutan saja menjadi wirausaha maka bisa dipastikan bahwa para peserta tidak akan bisa bertahan menjadi wirausaha yang sukses.

Pola pikir dan karakter wirausaha yang kedua menekankan kepada materi tentang berpikir dengan paradigma baru dan mulai meninggalkan masalah-masalah masa lalu yang dapat menjadi penghambat untuk mewujudkan keinginan menjadi wirausaha, karena wirausaha yang sukses memiliki karakter yang optimis memandang masa depan dengan memanfaatkan peluang yang ada disekitar mereka. Wirausaha yang masih memiliki pemikiran pesimis dan selalu tenggelam dengan pemikiran masa lalu tidak akan pernah sukses, sehingga sangat penting bagi wirausaha memiliki pola pikir dan karakter wirausaha yang berorientasi masa depan, bukan sibuk memikirkan masa lalu.

Setelah pemaparan materi, maka narasumber memberikan game dan roleplay tentang cara menghancurkan mental blok yang masih ada di pemikiran para peserta. Game 
dan roleplay ini dilakukan dengan cara setiap peserta maju kedepan dan wajib mematahkan satu buah pensil menjadi dua bagian dengan hanya menggunakan satu jari saja. awalnya peserta tidak percaya dan masih memiliki mental blok, namun setelah dicontohkan oleh narasumber, para peserta mulai percaya bahwa mereka bisa melakukan hal yang sama, bahkan ada peserta yang mampu mematahkan dua pensil sekaligus. Hal ini menunjukan bahwa para peserta telah berhasil untuk meningkatkan rasa percaya diri mereka dan menghilangkan mental blok yang selama ini ada didalam diri mereka.

Kegiatan pengabdian dihari kedua diakhiri dengan tanya jawab santai dengan para peserta yang terlihat jauh lebih bersemangat dan optimis untuk menjadi wirausaha karena telah berhasil untuk mengatasi mental blok yang ada didalam diri mereka.

3. Tantangan dan Peluang Wirausaha (Hari Ketiga)

Berdasarkan hasil kegiatan pengabdian dihari kedua tentang karakter wirausaha dan membebaskan mental blok bagi para kegiatan kecakapan wirausaha rumpun pariwisata dengan jenis keterampilan jasa usaha makanan di pusat kegiatan belajar mengajar (PKBM) Alkahfi, dapat diketahui bahwa para peserta telah memiliki pondasi pengetahuan dan kesiapan untuk menjadi wirausaha baru dan siap untuk mulai menerapkan karakter wirausaha didalam diri mereka.

Atas dasar kesiapan inilah, dihari ketika diberikan pemaparan tentang tantangan dan peluang wirausaha yang akan dihadapi oleh para kegiatan kecakapan wirausaha rumpun pariwisata dengan jenis keterampilan jasa usaha makanan di pusat kegiatan belajar mengajar (PKBM) Alkahfi. Materi tantangan ini memang sengaja diberikan dihari ketiga ketika para peserta memang telah siap secara mental dan motivasi untuk menjadi wirausaha, karena bila disampaikan saat mereka belum siap secara mental dan motivasi, bisa saja tantangan ini justru menjadi masalah yang membuat mereka menjadi takut dan ragu-ragu untuk memasuki dunia usaha.

Materi tantangan dan peluang usaha ini disampaikan dengan metode presentasi oleh narasumber dihadapan para peserta yang diselingi dengan tanya jawab. Materi ini lebih banyak berisi tentang tantangan dan peluang usaha dibidang kuliner mengingat para peserta nantinya belajar tentang usaha bidang kuliner, sehingga diharapkan para peserta bisa mengetahui gambaran utuh tentang situasi wirausaha bidang kuliner yang nantinya akan mereka hadapi.

Selain presentasi materi, diakhir sesi kegiatan, para peserta diwajibkan untuk maju kedepan dan melakukan presentasi secara individu untuk menjelaskan pengetahuan 
Prosiding The 1st National Conference on Applied Business, Education, \& Technology (NCABET)"

Unversitas Bina Bangsa 2021

DOI Article : 10.46306/ncabet.v1i1.13

apa yang sudah mereka dapatkan selama tiga hari proses kegiatan pengabdian pada masyarakat ini dan juga menjelaskan motivasi dan keinginan yang akan mereka lakukan kedepannya. Hal ini dilakukan sebagai bagian dari evaluasi kegiatan pengabdian pada masyarakat sehingga terukur pengetahuan yang didapatkan oleh para peserta kegiatan kecakapan wirausaha rumpun pariwisata dengan jenis keterampilan jasa usaha makanan di pusat kegiatan belajar mengajar (PKBM) Alkahfi.

Hasil dari presentasi individu menunjukan bahwa keseluruhan peserta sudah memahami karakteristik wirausaha serta memiliki motivasi yang tinggi untuk menjadi wirausaha baru dibidang kuliner sesuai dengan tujuan program kegiatan kecakaan wirausaha. Adapun materi yang sangat mereka ingat adalah materi menghancurkan mental blok serta materi tentang karakteristik wirausaha untuk menjadi wirausaha yang berhasil.

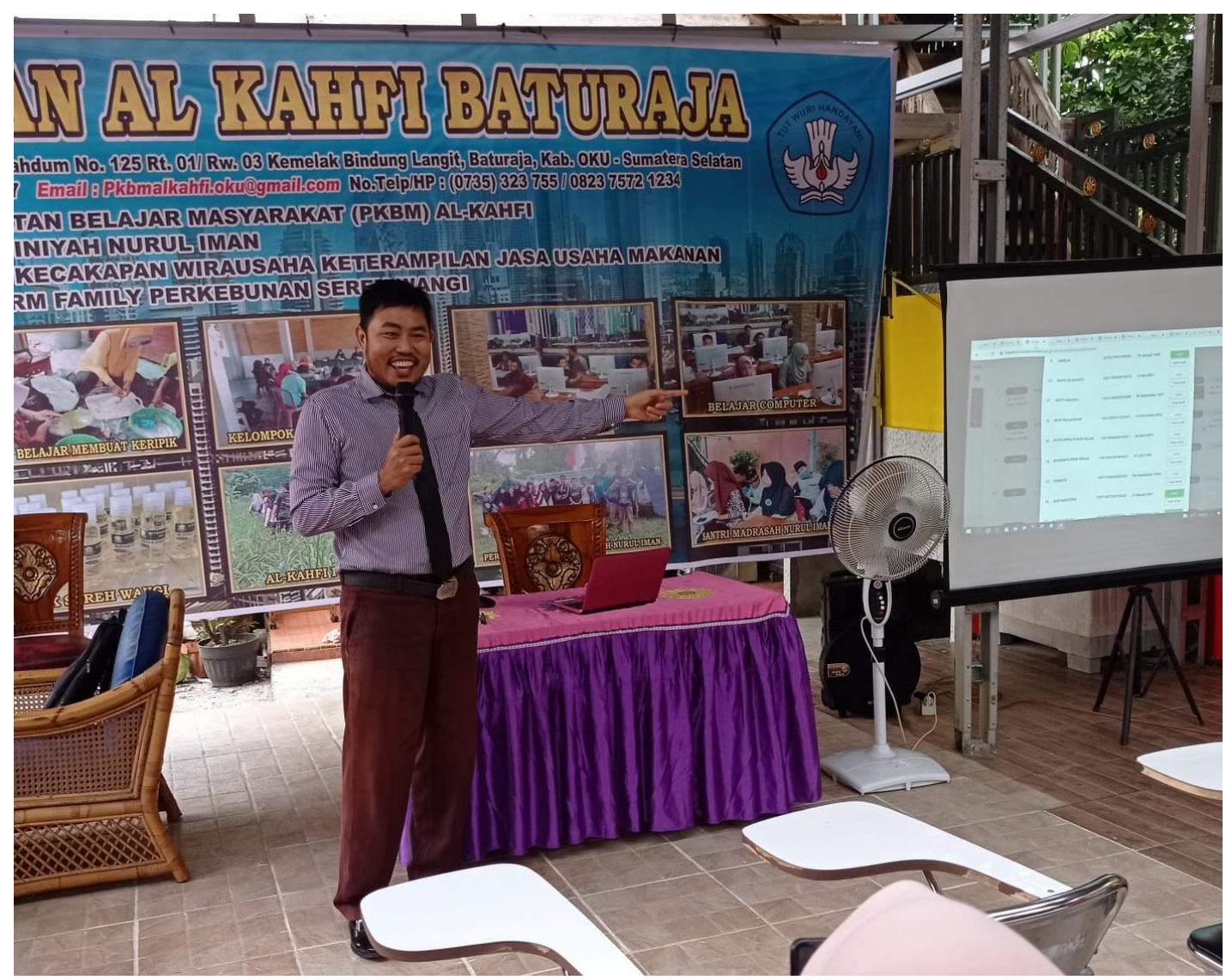

Gambar 1. Presentasi materi oleh salah satu narasumber 


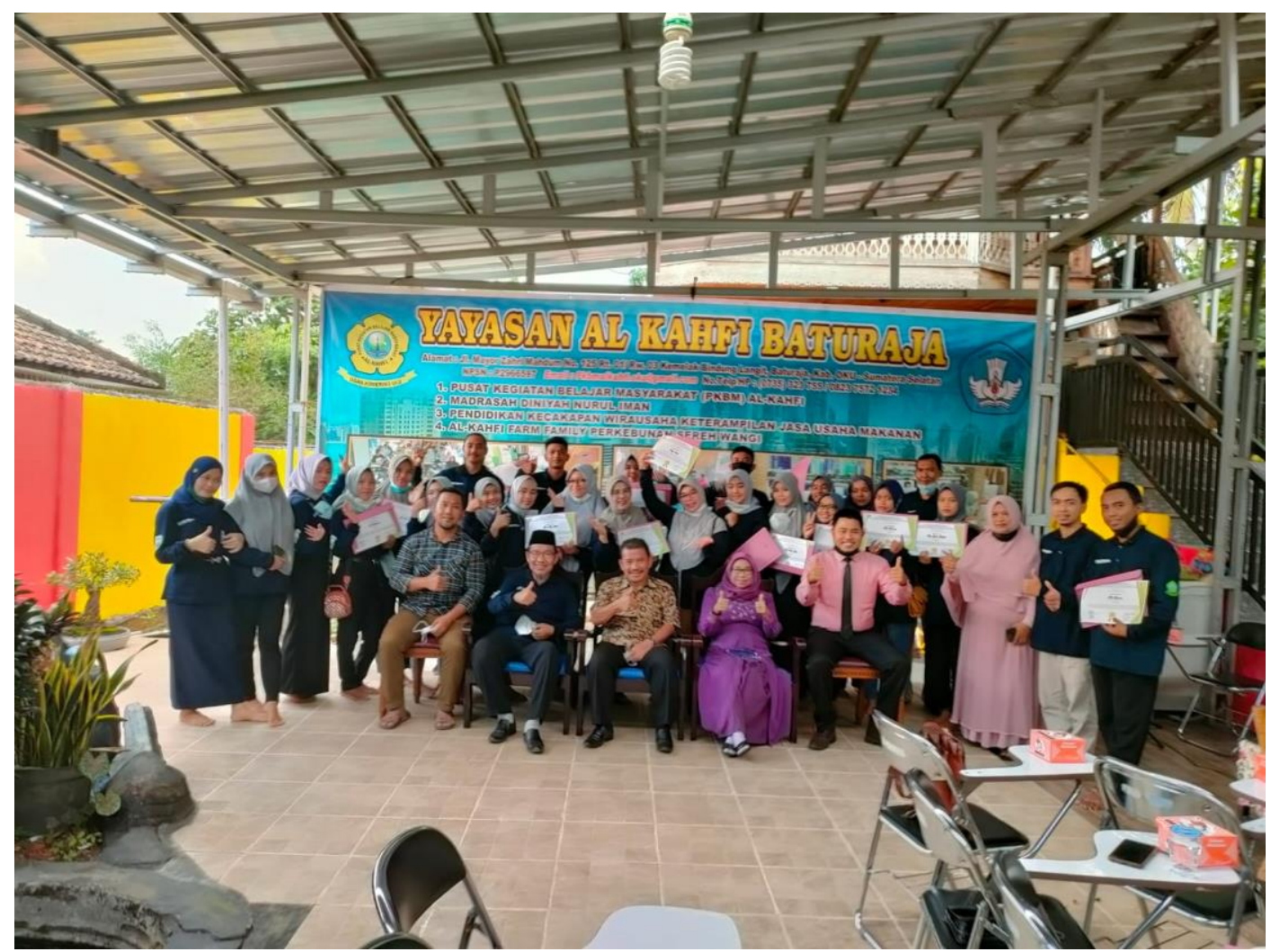

Gambar 2. Foto bersama peserta dan pengurus Yayasan PKBM Alkahfi

\section{KESIMPULAN}

Kegiatan pengabdian pada masyarakat pada program kegiatan kecakapan wirausaha rumpun pariwisata dengan jenis keterampilan jasa usaha makanan di pusat kegiatan belajar mengajar (PKBM) Alkahfi dengan materi karakteristik wirausaha telah berhasil untuk memberikan ilmu pengetahuan baru. Pengetahuan ini membuat para peserta berhasil memiliki pemahaman yang utuh tentang arti wirausaha, bagaimana memulai wirausaha, pola pikir dan mainset wirausaha serta membuat para peserta termotivasi dan siap untuk memulai menjadi wirausaha baru dibidang kuliner sesuai dengan harapan program kegiatan kecakapan wirausaha.

Kegiatan pengabdian pada masyarakat inipun menunjukan bahwa sangat penting untuk memberikan materi karakteristik kewirausahaan bagi para calon wirausaha baru agar mereka siap menghadapi tantangan dan menangkap peluang wirausaha yang ada disekitar mereka. Namun demikian penyampaian materi bagaimana mematahkan mental blok dan menanamkan strong reason bagi para peserta kegiatan memiliki efek yang sangat signifikan untuk memotivasi para peserta untuk berani dan optimis menjadi wirausaha baru dibidang kuliner.

\section{UCAPAN TERIMAKASIH}


Prosiding The 1st National Conference on Applied Business, Education, \& Technology (NCABET)"

Unversitas Bina Bangsa 2021

DOI Article : 10.46306/ncabet.v1i1.13

Penulis mengucapkan terimakasih kepada seluruh peserta program kegiatan kecakapan wirausaha rumpun pariwisata dengan jenis keterampilan jasa usaha makanan di pusat kegiatan belajar mengajar (PKBM) Alkahfi yang telah memberikan kepercayaan kepada kami untuk melaksanakan kegiatan pengabdian kepada masyarakat dengan materi karakter kewirausahaan.

\section{DAFTAR PUSTAKA}

Apip Alansori, S. E., \& Erna Listyaningsih, S. E. (2020). Kontribusi UMKM Terhadap Kesejahteraan Masyarakat. Penerbit Andi.

Barlian, I., Nawangpalupi, C. B., \& Maria, E. (2014). Peran Wirausaha Muda Terhadap Perkembangan Kewirausahaan Kreatif Di Bandung. Research Report-Humanities and Social Science, 1.

Dede Andi, S. E. (2021). Pola Pikir, Pengetahuan, Dan Keahlian Wirausaha. Entrepreneurial Mindsets $\backslash \&$ Skill, 21.

Fernando, E., \& Jamaaluddin, J. (2020). Peran Wirausaha Milenial Dalam Memajukan Perekonomian Bangsa. Pewira Usaha Sebagai Penopang Kemajuan Bangsa.

Mahesa, A. D., \& Rahardja, E. (2012). Analisis faktor-faktor motivasi yang mempengaruhi minat berwirausaha. Diponegoro Journal of Management, 1(4), 130-137.

Puspitasari, D. C. (2015). Wirausaha Muda Membangun Desa: Dinamika Partisipasi Pembangunan Desa. Jurnal Studi Pemuda, 4(2), 330-341.

Sarah, I. S., Putri, I. S. S., Amalia, S., Halilah, L., \& Tjahjawati, S. S. (2020). pendampingan wirausaha: solusi kegagalan wirausaha pemula. Jurnal DIFUSI, 3(1), 1.

Sulastri, L. (2016). Studi Kelayakan Bisnis Untuk Wirausaha. LGM-LaGood's Publishing.

Suryana, Y., \& Bayu, K. (2012). Kewirausahaan: Pendekatan Karakteristik Wirausahawan Sukses Ed. 2. Kencana. 